\title{
PENERAPAN HUKUM SECARA GRADUAL MELALUI KONSEP MAKKIYYAH DAN MADANIYYAH
}

\section{Muhammad Maksum}

Universitas Islam Negeri Syarif Hidayatullah Jakarta maksum.2010@gmail.com

\section{Abstract}

The concept of the Makkiyyah and Madaniyyah is not sufficiently understood as the classification of verses based on time, place, or substance of the verse revealed. The concept of Makkiyah and Madaniyyah also contains the graduation of society development and the determination of law. Society development starts from an uncivilized society towards civilized society (Medina). The graduation of law starts from the conception of a general arrangement towards a more detailed and specific arrangement along with the progress of human growth. The conception of the Makkiyyah and Madaniyyah is thus a legal and social conception, in the sense of showing the existence of graduation.

Keywords: Makkiyyah, Madaniyyah, Preaching, Gradually 


\section{Abstrak}

Konsep Makkiyyah dan Madaniyyah tidakcukup dipahami sebagai klasifikasi ayat berdasarkan waktu, tempat, ataupun substansi dari ayat yang diturunkan. Konsep Makkiyah dan Madaniyyah mengandung pula graduasi pembangunan masyarakat dan penetapan hukum. Pembangunan masyarakat berawal dari masyarakat yang tidak beradab menuju masyarakat beradab (madinah). Graduasi hukum berawal dari konsepsi pengaturan umum menuju pengaturan yang lebih detil dan spesifik seiring dengan majunya pertumbuhan manusia. Konsepsi Makkiyyah dan Madaniyyah dengan demikian merupakan konsepsi hukum dan sosial, dalam arti menunjukkan adanya graduasi.

Kata Kunci: Makkiyyah, Madaniyyah, Dakwah, Gradual 


\section{A. PENDAHULUAN}

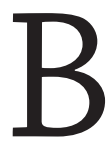
anyak teori yang membahas sebab-sebab kebangunan dan kemajuan masyarakat-masyarakat serta sebab-sebab kemunduran mereka. Pandangan satu aliran mengenai faktor utama kemajuan atau kemunduran, menunjukkan pendekatannya terhadap masyarakat dan sejarah serta gerakan mereka ke arah perkembangan dan kemunduran.

Nabi sebagai pelaku sejarah mempunyai peran besar dalam membangun masyarakat, karena di samping sebagai tokoh agama, nabi diutus sebagai revolusioner untuk merubah kebobrokan masyarakat yang keluar dari norma-norma yang benar ${ }^{1}$. Meski demikian banyak faktor yang mendukung peran nabi itu.

Al-Qur'an Suci, terutama dengan merujuk ke kisah-kisah dan anekdot-anekdot yang berhubungan dengan hal-hal ini, menerangkan pandangannya. Mesti kita lihat apakah al-Qur'an menafsirkan sebab-sebab perubahan secara apa yang disebut dasar atau bangunan. Untuk lebih tepatnya, mesti kita tahu hal-hal apakah yang dipandang oleh al-Qur'an sebagai dasar dan hal-hal apakah yang dipandang sebagai membentuk bangunan. Apakah alQur'an menekankan faktor-faktor bendawi dan ekonomi sebagai yang menjadi dasar, atau apakah Kitab Suci itu memberikan nilai penting mendasar pada hal-hal yang menyangkut keimanan dan moralitas? Atau, apakah al-Qur'an memandang seluruh faktor itu sebagai bertanggung jawab atas bangun jatuhnya suatu masyarakat tanpa menentukan yang paling bertanggung jawab di antara seluruh faktor itu? ${ }^{2}$

Masyarakat muslim ${ }^{3}$ yang dibangun Nabi Muhammad di Makkah dan Madinah adalah satu contoh dari sebuah masyarakat yang jatuh bangunnya ditentukan oleh, tidak hanya faktor

1 Ziaul Haq, Wahyu dan Revolusi, (Yogyakarta: LKiS, 2000), Cet. Ke-1, h. 33

2 Murtadha Mutahhahari, Masyarakat dan Sejarah, (Bandung: Mizan, 1998), Cet. Ke-6, h. 202

3 Istilah masyarakat muslim ini diambil dari istilah yang digunakan Fazlur Rahman dalam tulisannya tentang pembangunan masyarakat muslim yang sebenarnya, menurutnya telah dimulai pada periode Makkah bukan Madinah. Menurutnya, pembangunan masyarakat muslim berarti ajakan Muhammad untuk membentuk satu masyarakat satu agama, Islam, dan ini telah dimulai pada masa dakwah Nabi di Makkah. Lihat Fazlur Rahman, Tema Pokok al-Qur'an, terj. (Bandung: Pustaka, 1996), Cet. Ke-2, h. 194 dst. 
ekonomi dan sosial, tetapi juga didukung oleh nilai-nilai moral yang dibangunnya.

Persoalan nilai-nilai yang dibangun Nabi tidak bisa dilepaskan dari al-Qur'an, sebagai sumber pokok nilai-nilai itu. Adanya periodesasi Makkah dan Madinah menunjukkan adanya perkembangan pembangunan nilai-nilai moral dan sosial. Periodesasi ini yang kemudian mengelompokkan al-Qur'an ke dalam dua kelompok; ayāt Makkiyyah dan Madaniyyah, yang mempunyai ciri dan kekhasan masing-masing.

Antara pembangunan masyarakat Islam dan pembagian ayāt ini mempunyai hubungan yang relevan. Artinya, ayāt-ayāt itu menunjukkan adanya interaksi dengan sejarah dan realitas ${ }^{4}$ yang berbeda, sehingga nash pun berbicara berbeda.

Terlepas dari berbagai pendapat yang ada dengan segala perbedaan dan variasinya, yang pasti al-Qur'an untuk pertama kali diturunkan pada malam hari bulan Ramadhan yang oleh al-Qur'an dijuluki dengan malam Lailah al-Qadar dan malam yang diberkahi, Lailah Mubarakah.

Dan sudah merupakan kesepakatan (jumhur ulama) bahwa alQur'an diturunkan kepada Nabi Saw. secara berangsur-berangsur sejalan dengan peristiwa yang menyertainya. Nash turun sebagai respon atau memberi nilai atas budaya dan tradisi yang berjalan.

\section{B. KONSEP MAKKY DAN MADANY}

Pembagian ayat Makkiyyah dan Madaniyyah dapat dilihat dari empat perbedaan yang ada:

1. Waktu turunya

Pembagian ayat itu didasakan pada hijrah Nabi, ayat yang turun sebelum hijrah Nabi meskipun turun di luar Makkah dianggap sebagai ayat/surat Makkiyyah, sementara yang turun setelah hijrah meskipun turun di daerah selain Madinah

4 Nasr Hamid Abu Zaid, Tekstualitas al-Qur'an: Kritik Terhadap 'Ulūm al-Qur'an, terj. (Yogyakarta, LkiS, 2001), h. 93 
dikategorikan sebagai ayat/surat Madaniyyah. ${ }^{5}$ Dengan demikian tidak semua ayat/surat yang turun di Makkah dikatakan ayat Makkiyyah, demikian pula tidak semua ayat yang turun di Madinah dikatakan sebagai ayat Madaniyyah.

2. Tempat turun

Ayat yang turun di daerah Makkah dan sekitarnya; Mina, 'Arafah, dan Hudaibiyah dikategorikan sebagai ayat Makkiyyah dan yang turun di Madinah dan sekitarnya; Uhud dan Qaba' dianggap sebagai Madaniyyah.

3. Orang yang diseru

Ayat Makkiyyah adalah ayat yang diturunkan kepada penduduk Makkah, sementara ayat yang diturunkan kepada penduduk Madinah dikatakan sebagai ayat Madaniyyah.

4. Isi (Content)

Yang dikategorikan ayat Makkiyyah adalah yang berisi tentang cerita-cerita umat dan para nabi/rasul terdahulu. Sedang yang disebut Madaniyyah adalah yang berisi seputar hukum hudud, faraid, dan sebagainya. ${ }^{6}$ Secara luas perbedaan Makkiyyah dan Madaniyyah dan sisi isi itu dapat dijelaskan sebagai berikut:

a. Surat Makkiyyah penuh dengan ungkapan-ungkapan yang kedengaranya amat keras di telinga, huruf-hurufnya seolah melontarkan api ancaman dan siksaan, masingmasing sebagai penahan dan pencegah, sebagai pembawa malapetaka. Seperti dalam surat Qariah, Ghasyiah dan Waqiah. Kemudian dengan huruf-huruf hijaiyah pada permulaan surat dan ayat-ayat berisi tantangan di dalamnya, nasib umat terdahulu, bukti-bukti alamiah dan yang dapat diterima akal.

b. Surat Makkiyyah di dalamnya terdapat ayat Sajdah, ada lafadh "Kalla", menggunakan seruan "yā-ayyuhan nāsu",

5 Manna' al-Qaththan, Mabāhits fi 'Ulüm al-Qur'an, (Mansyurat al-'Ashr al-Hadits), h. 61

6 Jalāl al-Dîn al-Suyūthi, Al-Itquān fi 'Ulūm al-Qur'an, (Beirut: Dar al-Fikr, tt.), h. 9 
tiap-tiap surat yang mengandung kisah Nabi-nabi dan umatumat yang lalu, surat yang ada di dalamnya kisah Adam dan Idris, tiap-tiap surat yang dimulai dengan huruf at-Tahajji. Ini adalah ciri yang khusus. Sedangkan Aghlabiahnya: ayatayatnya pendek-pendek, surat-suratnya pendek-pedek, nada perkataannya keras dan agak bersajak. Mengandung seruan kepada pokok-pokok iman kepada Allah, hari akhir dan menggambarkan keadaan surga dan neraka. Menyeru manusia kepada berperang mulia dan kebajikan. Mendebat orang musrikin dan menerangkan kesalahan mereka. Banyak terdapat lafadh sumpah?

Misalnya,

$$
\text { قد نعلم انه ليحزنك الذى يقولون .... }
$$

"Sesungguhnya Kami mengetahui bahwasanya apa yang mereka katakan itu menggundahkan hati engkau”. (QS. 6: alAn'am: 3 3).

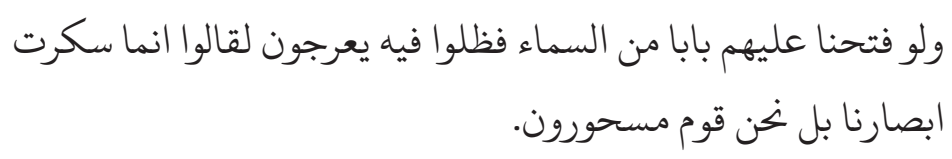

"Dan jikalau Kami buka untuk mereka pintu dan langit, lalu mereka terus-menerus naik padanya tentulah mereka berkata: sesungguhnya telah dimabukkan pandangan-pandangan kami. Bahkan kami adalab orang-orang yang kena sihir". ( QS. 15: al-Hijjr, 14 dan 15).

Demikianlah surat-surat Makkiyyah banyak mengandung peringatan terhadap orang-orang musyrik yang biadab.

Al-Qaththan mengatakan, surat Makkiyyah penuh dengan ungkapan-ungkapan yang kedengarannya amat keras di telinga, huruf-hurufnya seolah melontarkan api ancaman dan siksaan, masing-masing sebagai penahan dan pencegah, suara pembawa mala petaka, seperti dalam

7 Abdul Djalal H.A., Ulumul Qur'an, (Surabaya: Dunia Ilmu, 1998), h. 89 
surat Qari'ah, Ghasyiah dan Waqi'ah.

c. Surat Madaniyyah

Ayat atau surat Madaniyyah adalah Suratnya berisikan kewajiban atau had, menyebutkan orang munafik, terdapat dialog dengan ahli kitab. Dan bila dilihat tema dan gaya bahasanya, surat Madaniyyah menjelaskan ibadah, muamalah, had, kekeluargaan, warisan, jihad, hubungan sosial, hubungan internasional, baik di waktu damai maupun perang, kaidah hukum dan masalah perundangundangan. Menceritakan tentang bahaya orang-orang munafik serta suku kata dan ayatnya panjang-panjang dan dengan gaya bahasa yang memantapkan syariat serta menjelaskan tujuan dan sasarannya.

Para ahli tafsir tidak sekata dalam menetapkan jumlah surat yang diturunkan di Madinah. Bahkan mereka berselisih paham pula tentang menentukan surat-surat Makkiyyah dan tentang surat-surat Madaniyyah. Antara lain al-Khudlary, menetapkan bahwa jumlah al-Qur'an yang turun di Makkah sejumlah 19/30 dan yang turun di Madinah sejumlah 11/30. Surat-surat yang turun di Makkah 91 dan turun di Madinah sejumlah 23. Munawar Khalil mengatakan di Makkah sebanyak 86 surat dan di Madinah 28 surat. Namun bila kita periksa aI-Muskhaf yang kita perhatikan keterangan-keterangan yang terdapat dipermukaan tiap-tiap surat nyatalah bahwa surat yang turun di Makkah sejumlah 86 dan yang turun di Madinah 28, jadi jumlahnya 114 Surat. ${ }^{8}$ Dan ini disepakati oleh jumhur ulama. Kesimpulan ini tidak bermaksud menafikan pendapat yang satu atau membenarkan yang lainnya. Karena perbedaan itu dapat saja dimaklumi karena dari awal mereka sudah berbeda yaitu dalam menentukan berapa lama Nabi di Makkah dan perbedaan mendefinisikan surat Makkiyyah dan Madaniyyah itu sendiri.

8 Ada yang berpendapat 113 surat, karena surat al-Anfāl dan al-Taubah dihitung satu surat. Syi'ah mengatakan 116 surat, yaitu ditambah dengan yang mereka sebut surat al-Khal'u atau alKhafdu. 
Oleh karena itu, para ahli (Ulumul Qur'an) menetapkan dua cara untuk menentukan apakah surat itu Makki atan Madani. (1) Sima'i naqli/sama'i (jalan riwayat, dan (2) Qiyasi ijtihadi/qiyasi (jalan membandingkan yang satu dengan yang lainnya). ${ }^{9}$

Dengan dasar ini bukanlah hal yang sulit untuk membenarkan bila ada yang berpendapat bahwa di dalam surat Makkiyyah dan Madaniyyah tidak seluruhnya merupakan ayat Makkiyyah dan Madaniyyah. Artinya dalam surat Makkiyyah dan Madaniyyah atau sebaliknya. Diantara contohnya QS. Al-Anfāl (Madaniyyah), tetapi banyak ulama mengecualikan ayat 30 (Makkijyah).

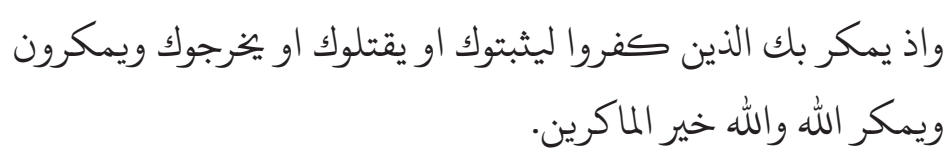

"Dan \{ingatlah\} ketika orang kafir (Qurais) membuat makar terhadapmu untuk menangkap dan mengajarkanmu atau membunuhmu atau mengusirmu, mereka membuat makar, tetapi Allah mengagalkan makar mereka dan Allah adalah sebaik-baik pembalas makar" (QS. al-Anfāl/8: 30)

\section{KONDISI MAKKAH DAN MADINAH}

Pembahasan hal ini penting karena untuk melihat bagaimana pergeseran norma Islam dan institusinya tatkala di Makkah dan Madinah yang sekaligus menunjukkan adanya perubahan orientasi dakwah Nabi.

Masyarakat Arab bukanlah masyarakat yang bodoh akan ilmu pengetahuan dan ekonomi. Pasar 'Ukaz, adalah semacam auditorium yang digunakan untuk festival dan pagelaran seni

\footnotetext{
9 Manna al-Qaththan, Op. Cit., h. 60. Abdul Djalal menambahkan bahwa dasar penetapan Makkiyyah dan Madaniyyah itu ada dua; (1) dasar aghlabiyyah (mayoritas), yaitu jika sesuatu surat itu mayoritas atau kebanyakan ayat-ayatnya Makkiyyah, dan sebaliknya jika mayoritas ayatnya Madaniyyah dikelompokkan sebagai surat Madaniyyah. (2) Dasar taba'iyah (kontinyuitas), jika ayat itu didahului dengan ayat Makkah dikelompokkan Makiyyah dan jika didahului Madinah dikelompokkan Madaniyyah.
} 
sastra. Masyarakat Arab kaya akan gaya bahasa dan ungkapanungkapan ${ }^{10}$.

Problem mereka, baik masyarakat yang nomadik maupun menetap adalah bercokolnya budaya kesukuan Badui. Organisasi dan identitas sosial berakar pada keanggotaan dalam suatu rentang komunitas yang luas. Kelompok beberapa keluarga membentuk kabilah (clan). Beberapa kelompok kabilah membentuk suku (tribe) dan dipimpin oleh seorang syekh. Mereka sangat menekankan hubungan kesukuan sehingga kesetiaan atau solidaritas kelompok menjadi sumber kekuatan bagi suatu kabilah atau suku. Mereka suka berperang. Karena itu, peperangan antar suku sering sekali terjadi. Sikap ini nampaknya telah menjadi tabiat yang mendarah daging dalam diri orang Arab. Dalam masyarakat yang suka berperang tersebut, nilai wanita menjadi sangat rendah. Situasi seperti ini terus berlangsung sampai agama Islam lahir.

Dunia Arab ketika itu merupakan kancah peperangan terus menerus. Pada sisi yang lain, meskipun masyarakat Badui mempunyai pemimpin, namun mereka hanya tunduk kepada syekh atau amir (ketua kabilah) itu dalam hal yang berkaitan dengan peperangan, pembagian harta rampasan dan pertempuran tertentu. Di luar itu, syekh atau amir tidak kuasa mengatur anggota kabilahnya. ${ }^{11}$

Masyarakat Makkah adalah masyarkat nomadik yang kental dengan patriarkhinya yang berbudaya kasar, berbeda dengan masyarakat Madinah adalah masyarakat bertani yang penuh dengan kedamaian. Budaya tulis menulis lebih berkembang di Madinah dari pada Makkah.

Masyarakat Makkah secara moral telah bobrok; menyembah banyak tuhan, tidak menghargai wanita, minuman keras, dan lain sebagainya. Sementara di Madinah, agama Yahudi dan Nasrani dipraktekkan oleh banyak masyarakat dan etos kerja mereka tinggi.

Problem masyarkat Makkah inilah yang menjadikan Nabi sulit

10 Badri Yatim, Sejarah Peradaban Islam, (Jakarta: Rajawali Press, 1997), Cet. Ke-6, h. 12

11 Ibid., h. 11. 
berdakwah di sana dan berpindah ke Madinah. Perpindahan inilah yang kemudian disebut sebagai Hijrah Nabi.

\section{HIJRAH NABI: AWAL PEMBANGUNAN MASYARAKAT ISLAM}

Hijrah menandai tidak saja perubahan dramatik pertumbuhan jumlah umat Islam dan pembentukan masyarakat politik atau negara Islam pertama di Madinah, melainkan juga peralihan yang signifikan dalam materi pokok dan isi missi Nabi. Secara umum disepakati bahwa selama periode Makkah, al-Qur'an dan Sunnah lebib banyak berisi tentang ajaran agama dan moral, tidak menyatakan norma-norma politik dan hukum secara khusus, yang baru dikembangkan pada periode Madinah. Penjelasan tentang perubahan ini adalah karena pada periode Madinah ini al-Qur'an dan Sunnah harus memberikan respons terhadap kebutuhan sosial politik yang konkrit dalam suatu komunitas yang dibangun. Dengan kemerdekaan untuk mengembangkan institusi-institusi yang mereka miliki dan menerapkan norma-norma agama baru mereka, umat Islam memerlukan ajaran dan tuntunan yang lebih terinci.

Signifikansi perubahan isi pesan tersebut (sebagaimana dibedakan dengan materi pokoknya), belum begitu jelas dan tidak mendapatkan perhatian yang memadai di masa lalu. Perubahan itu tidak hanya dari umum ke khusus, dan masalah agama dan moral ke masalah politik dan hukum, melainkan juga perubahan dalam makna dan implikasi al-Qur'an dan Sunnah ${ }^{12}$. Namun norma-norma politik dan hukum spesifik dari al-Qur'an dan Sunnah periode Madinah itu tidak selalu mencerminkan makna dan implikasi pesan yang pasti sebagaimana yang diwahyukan di Makkah. Suatu penyesuaian harus dibuat, dan telah berhasil dilakukan, untuk mendukung masyarakat politik dalam konteks sejarah dan geografis tertentu. 28.

12 Abdullah Ahmed an-Na'im, Dekonstruksi Syari'ah, (Yogyakarta: LkiS, 1994, Cet. Ke-1), h. 27- 


\section{E. DARI UNIVERSALISME KE EKSLUSIVISME}

Pada bagian atas di atas disebutkan bahwa ayat Makkah menyeru kepada seluruh umat manusia dan memperlakukan seluruh manusia sama sebagai makhluk Allah yang diperintah untuk menyembah Allah. Misi dakwah Nabi adalah membebaskan manusia dari keterkungkungan terhadap selain Allah ${ }^{13}$. Dakwah periode Makkah adalah dakwah inklusive atau universal untuk seluruh umat manusia. Dakwah dengan misi pembebasan manusia di Makkah ini berusia 13 tahun.

Sisa sepuluh tahun kehidupannya setelah hijrah, Nabi memusatkan perhatian pada konsolidasi masyarakat Muslim di Madinah dan sekitarnya. Negara Madinah adalah model negara yang diciptakan oleh Nabi. Periode ini, menurut an-Na'im, adalah periode dakwah ekslusive. Orang non muslim tidak lagi di samakan (atau diseru bersama orang muslim), dengan orang muslim, mereka adalah orang lain; ahl al-kitab, munafik, kafir, musyrik dan lain sebagainya. Menurut Muthahhari, konsep yang dibangun Nabi dalam rangka pembangunan masyarakat muslim adalah; penegakan keadilan, persatuan, amar ma'ruf nahi munkar, dan pembenahan moral. Menurut Muthahhari aspek-aspek ini berpengaruh pada jatuh bangunnya masyarakat. ${ }^{14}$

Tidak terhenti di situ, kekuasaan Madinah mempunyai legitimasi untuk memerangi kelompok musuh karena telah mempunyai kekuatan politik dan massa. Dakwah Islam di Madinah menjadi ekslusif.

\section{F. GRADULITAS DALAM PENERAPAN HUKUM}

Dalam pembahasan terdahulu telah disinggung bahwa perbedaan antara Makky dan Madany dalam teks merupakan perbedaan antara dua fase penting yang memiliki andil dalam

13 Makna Tauhid Lā ilaāha illa Allah, tiada tuhan selain Allah adalah konsep pembebasan manusia dari ketergantungan terhadap selaian Allah. Islam mendakwahkan kebebasan yang hakiki bagi manusia. Lihat Nurcholish Madjid, Islam Doktrin dan Peradaban, (Jakarta: Paramadina, 2000), Cet. ke-4, h. 3-4.

14 Murtadha Muthahhari, Op. Cit., h. 203-204 
membentuk teks, baik dalam tataran isi ataupun struktur. Hal ini berartibahwa teks merupakan buah dan interaksinya dengan realitas yang dinamis-historis. Ilmu makky dan madany mengungkapkan gejala-gejala umum dari interaksi tersebut, sementara hal-hal yang bersifat spesifik dan parsial ditunjukkan dalam ilmu tentang asbāb al-nuzūl. Dengan demikian tidak aneh dalam pemberlakuan hukum dan syari'ah (tasyrī') mengalami graduasi karena adanya interaksi dengan realitas itu.

Syariat diturunkan secara bertahap mengandung pengertian bahwa syari'at itu bersifat realistis, mengarahkan dan membantu manusia secara bertahap dan sedikit demi sedikit untuk melepaskan diri dari kejahiliahan dan adat istiadat yang telah mengakar, dan untuk menjadikan Islam dan nilai-nilai moral tinggi sebagai karakter utama.

Dalam pandangan Abu Zaid, inilah yang dikatakan sebagai fase dakwah inżār dan periode dakwah risālah. Peristiwa hijrah dari Makah ke Madinah bukan sekadar pindah tempat. Apabila fase dakwah di Makkah nyaris terbatas pada batas-batas inżār hanya memberi peringatan, belum sampai menyentuh batas-batas risālah kecuali hanya sedikit maka perpindahan ke Madinah mengubah wahyu menjadi risālah. Inżār berkaitan dengan pergulatan (perubahan) konsep-konsep lama pada taraf kognitif dan terkait dengan seruan menuju konsep-konsep baru. Inżār, dengan demikian, menggerakkan kesadaran bahwa ada kerusakan dalam realitas, dan oleh karena itu harus diadakan perubahan. Sementara risālah bertujuan membangun ideologi masyarakat baru.

Sebagai contoh gradualitas hukum Islam adalah pada maslah minuman keras. Tahap pertama Tuhan menyampaikan bahwa betul khamr itu ada manfaat dan mudharatnya, namun mudharatnya lebih besar. Tahap kedua, Tuhan melarang orang yang mabuk mendekati shalat. Dan baru tahap ketiga Tuhan mengharamkan khamr. 


\section{G. KESIMPULAN}

Pembangunan masyarakat muslim dari kaca mata misi dakwah Islam mengalami penyempitan. Artinya dakwah Islam tatkala di Makkah bersifat universal menjadi eskslusif tatkala di Madinah.

Pembangunan hukum masyarakat Islam dilakukan secara bertahap. Hal ini karena adanya interaksi antara teks dan realitas. Dilema teks dan realitas, satu sisi teks statis dan sisi lain realitas berkembang terus menjadikan keduanya saling bergumul. Namun karena teks adalah bersifat Ulūhiyyah, bersifat ketuhanan, mengatasi sejarah dan realitas manusia.

Konsep Makki dan Madani, harus dipandang dari sisi yang luas, tidak semata fiqhiyyah karena akan terjebak pada persoalan tempat dan waktu. Padahal konsep ini mengandung adanya dinamika pada struktur dan nilai moral yang disampaikan melalui teks. 


\section{DAFTAR PUSTAKA}

Nasr Hamid Abu Zaid, Tekstulaitas al-Our'an: Kritik Terhadap Ulumul Qur'an, (terj.) (Yogyakarta: LKiS, 2001)

Abdul Djalal, Ulumul Our 'an, Surabaya: Dunia Ilmu, 1998.

Ziaul Haq, Wahyu dan Revolusi, (Yogyakarta: LKiS, 2000), Cet. Ke-1

Rifat Syauqi Nawawi dan M. Au Hasan, Penganlar Ilmu Tafsir, Jakarta: Bulan Bintang, 1992.

Abdullah Ahmed an-Na'im, Dekonstruksi Syariah, (Yogyakarta: LkiS, 1994, Cet. Ke-1)

Nurcholish Madjid, Islam Doktrin dan Peradaban, (Jakarta: Paramadina, 2000), Cet. ke-4, h. 3-4

Fazlur Rahman, Tema Pokok al-Qur'an, terj. (Bandung: Pustaka, 1996), Cet. Ke-2

Manna' al-Qaththan, Mabahîts fi 'Ulūm al-Our'an, (Masyurat al'Ashr al-Hadits, t.t.)

Jalāl al-Dîn al-Suyūthi, Al-Itqān fi 'Ulūm al-Qur'an, (Beirut: Dar alFikr, tt.)

Badri Yatim, Sejarah Peradaban Islam, (Jakarta: Rajawali Press, 1997), Cet. Ke-6 